\title{
ÁGUA, AR, TERRA E FOGO: ARQUÉTIPOS DAS CONFIGURAÇÕES DA IMAGINAÇÃO POÉTICA NA METAFÍSICA DE GASTON BACHELARD
}

Alexander de Freitas*

\begin{abstract}
RESUMO
O objetivo deste artigo é discutir e sistematizar as configurações da imaginação poética propostas pela metafísica de Gaston Bachelard, relacionando-as aos arquétipos dos quatro elementos (água, ar, terra e fogo). Conduzindo a análise através da relação dialógica entre o simbolismo do elemento material e sua síntese em uma das cinco configurações da imaginação poética, encontrouse a imaginação material estruturada pelo elemento água, a imaginação dinâmica (do movimento) situada pelo elemento ar, a imaginação dinâmica (das forças) configurada pelo elemento terra e a imagem-lembrança e a imaginação arquetipal, ambas, arregimentadas pelo elemento fogo. Por fim, pode-se concluir que a hermenêutica tetra elementar utilizada na proposição das configurações da imaginação poética é vivida e confessada pelo próprio filósofo, sendo a obsessão pelo elemento fogo, o que vai iluminar a epistemologia e a metafísica poética de Gaston Bachelard.
\end{abstract}

Palavras-chave: Gaston Bachelard. Metafísica. Imaginação poética.

\begin{abstract}
The aim of this article has been to discuss and to systematize the structures of poetical imagination as proposed in Gaston

Doutorando do Programa de Pós Graduação em Educação da Faculdade de Educação da Universidade de São Paulo.
\end{abstract}

Educ. e Filos., Uberlândia, v. 20, n. 39, p. 39-70, jan./jun. 2006. 
Bachelard's metaphysics, by relating them to the archetypes of the four elements (water, air, earth and fire). Conducting the analysis through the dialectic relation between both, the symbolism represented by the material element, as well as its synthesis in one of the five structures of poetic imagination, it has been possible to understand the materialistic imagination represented by the element water, the dynamic imagination (movement) by the element air, the dynamic imagination (forces) represented by the element earth, as well as the memory-image and the archetypal imagination, both of them, considered by the element fire. At last, it can be concluded that the tetra elementary hermeneutics used in the proposition of the structures of poetical imagination is lived and confessed by the philosopher himself and the obsession for the element fire is what illuminates Gaston Bachelard's epistemology and metaphysics.

Keywords: Gaston Bachelard. Metaphysics. Poetical imagination.

Onde foi parar a relação característica da imagem materna para com a terra, com o escuro e abissal do homem corpóreo, para com seus instintos animais e sua natureza passional e para com a 'matéria' de modo geral? (Jung, 2002, p. 114)

\section{Introdução}

Na epígrafe acima, Carl Gustav Jung sintetiza os tácitos pilares de sustentação da vertente noturna ${ }^{1}$ da filosofia de Gaston Bachelard: o escuro e abissal do homem corpóreo, seu instinto

1 O termo "vertente noturna" que utilizamos acima foi criado em oposição ao termo "Bachelard diurno" utilizado por Pessanha (1994) para caracterizar a vertente epistemológica da filosofia de Bachelard fundada na "interminável aventura de clarificação e correção de conceitos" (p.5), referendada pela relação entre Bachelard diurno e Apolo, o deus solar da mitologia grega: "Bachelard diurno da epistemologia, do apolíneo reino dos conceitos" (p. 9). Assim, quando dissermos "vertente noturna", vamos nos referir, exclusivamente, à metafísica da imaginação poética

Educ. e Filos., Uberlândia, v. 20, n. 39, p. 39-70, jan./jun. 2006. 
animal, sua natureza passional, tudo isso, temperando e atualizando a ancestralidade da prima-matéria, da matéria alquímica. À metafísica da imaginação poética bachelardiana, basta que um estímulo material resvale a epiderme -nosso maior órgão cinestésico- para que a sensação e o êxtase, animados pelo inconsciente, floresçam através das matérias, revelando a imagem poética. Na voz de Bachelard (1998, p. 9): "é na carne, nos órgãos, que nascem as imagens materiais primordiais".

Importa situar que esta fenomenologia da sensação e do êxtase material, que configura a metafísica da imaginação poética de Bachelard, inicia-se entre 1938-1942, época em que, segundo Barbosa (1993, p. 111), a psicanálise sequer tinha direito à cidadania no ensino universitário. Enquanto mensageiro dos futuros mestres que formulariam as teorias contemporâneas do imaginário (ARAÚJO, 2003, p. 24), Bachelard postula, precocemente, a tensão indissociável -e inadiável- "corpo-matéria-imaginação", mediada pela emoção.

Deste modo, conduzido pelas rupturas paradigmáticas do novo espírito científico (BACHELARD, 1968) à luz da física relativista e, guiado pela possibilidade de invenção da realidade apreendida do ultra-racionalismo (BACHELARD, 1974) e da fenomenotécnica (BACHELARD,1990c), Bachelard cria uma sistemática de investigação da gênese da imagem poética -do imaginário literárioa partir do arquétipo ${ }^{2}$ dos quatro elementos: "a regularidade do

bachelardiana, que procede à inversão da catarse substancialista pela pureza conceitual, em êxtase cenestésico pela vivência com a matéria. A respeito desta relação dialógica entre estes dois delineamentos opostos e complementares da filosofia de Bachelard, freqüentemente expressos pelos epítetos "diurno" e "noturno", ver nosso artigo "Apolo-Prometeu e Dioniso: dois perfis mitológicos do 'homem das 24 horas' de Gaston Bachelard", Rev. Fac. Educ., 32 (1), 2006.

2 Utilizamos o termo arquétipo no sentido que lhe atribui Jung (2002) de imagens universais que, por representarem situações típicas na vida e, por serem repetidas desde tempos imemoriais, imprimiram essas experiências na constituição psíquica do homem, representando possibilidades de um determinado tipo de percepção e ação sobre a realidade. O conceito de arquétipo na acepção jungiana se refere às representações coletivas e primordiais, isto é, às imagens do inconsciente coletivo que vão representar o modelo básico do comportamento instintivo humano.

Educ. e Filos., Uberlândia, v. 20, n. 39, p. 39-70, jan./jun. 2006 
imaginário se deve ao fato de sermos arrebatados na pesquisa imaginária por 'matérias fundamentais', por elementos imaginários que têm leis idealistas tão seguras como as leis experimentais" (BACHELARD, 2001c, p. 7). Somos "arrebatados" -no mais puro sentido dionisíaco- pela prima-matéria: o imaginário evidenciado na metafísica bachelardiana é relação dialógica "homem-matéria", é revisitação da alegoria materialista alquímica:

Se nosso presente trabalho pudesse ter utilidade, deveria sugerir uma classificação dos temas objetivos que preparassem uma classificação dos temperamentos poéticos. Ainda não chegamos a elaborar em detalhe uma doutrina de conjunto, mas pensamos que há uma relação entre a doutrina dos quatro elementos e a doutrina dos quatro temperamentos. Em todo caso, as almas que sonham sob o signo do fogo, sob o signo da água, sob o signo do ar e sob o signo da terra revelam-se muito diferentes entre si. (BACHELARD, 1999b, p. 132)

É assim que a metafísica da imaginação poética de Bachelard, surrealizando a crítica literária orientada pela história de vida do poeta, pelo determinismo sócio-cultural, e, pelo ranço positivista de negligência à imagem, vai estabelecer quatro domínios elementares que estruturam a imaginação poética, daí que: "dizeme qual é o teu infinito e eu saberei o sentido do teu universo; é o infinito do mar ou do céu, é o infinito da terra profunda ou da fogueira?" (BACHELARD, 2001c, p. 6). Esta "química" -ou melhor, esta alquimização- do devaneio poético, temperada ao sabor dos quatro elementos da física aristotélica, esteio metodológico que organiza a metafísica poética de Bachelard, aparece poeticamente representada na seguinte passagem:

Diz-me qual é teu fantasma: o gnomo, a salamandra, a ondina ou a sílfide? Por acaso já não se observou que todos esses seres quiméricos são formados e nutridos de uma matéria única? O gnomo terrestre e condensado vive na fenda do rochedo, guardião do mineral e do ouro, repleto das

Educ. e Filos., Uberlândia, v. 20, n. 39, p. 39-70, jan./jun. 2006. 
substâncias mais compactas; a salamandra de fogo devorase em sua própria chama; a ondina das águas desliza-se sem ruído sobre o lago e alimenta-se de seu reflexo; a sílfide, a quem a menor substância pesa, a quem a menor quantidade de álcool amedronta, que se zangaria talvez com um fumante que "suja seu elemento" (Hoffmann), eleva-se sem dificuldade no céu azul, satisfeita com sua anorexia. (BACHELARD, 1999b, p. 133)

Ao centrar sua metafísica nos desdobramentos simbólicos dos quatro elementos, Bachelard desenvolve sistematizações do devaneio poético que chamaremos, por falta de termo melhor, de configurações da imaginação poética. Neste sentido, o gnomo, alegoria da imaginação terrestre, vai situar a imaginação da intimidade, o apelo à introversão presente em "A terra e os devaneios do repouso"; a salamandra à semelhança da fênix, manifestação que atualiza as imagens ancestrais do fogo, vai configurar o poder do arquétipo na gênese da imagem poética; a ondina, com sua longa cabeleira, materializa, ela mesma, através da analogia -"o rio move-se como uma cabeleira viva" (BACHELARD, 1998, p. 86) - a imagem sedutora da Mãe d'água, exemplo privilegiado do que Bachelard vai chamar de imaginação de causa material; por fim, a sílfide, sem matéria, produto do dinamismo aéreo do mais leve dos elementos -"o ar natural é o ar livre" (BACHELARD, 2001c, p. 8)- vai personificar uma das configurações da imaginação dinâmica bachelardiana.

À luz da metafísica de Bachelard jorram imagens materiais "um elemento material é o princípio de um bom condutor que dá continuidade a um psiquismo imaginante" (BACHELARD, 2001c, p. 8)- que serão arregimentadas pelo poder agregador dos arquétipos tetra-elementares, gerando configurações da imaginação que aparecem explicitadas nos subtítulos das obras sobre os quatro elementos: "A água e os sonhos: ensaio sobre a imaginação da matéria", "O ar e os sonhos: ensaio sobre a imaginação do movimento", "A terra e os devaneios da vontade: ensaio sobre a imaginação das forças" e "A terra e os devaneios do repouso: ensaio sobre as imagens da intimidade".

Educ. e Filos., Uberlândia, v. 20, n. 39, p. 39-70, jan./jun. 2006. 
Apesar da irreverência à estruturação positivista da crítica literária e da criação de uma hermenêutica simbólica -materialista e alquímica- na investigação do imaginário literário, esta vertente noturna da filosofia bachelardiana, finalizada, com a morte do seu autor, em 1962, permanece ainda pouco conhecida e utilizada como referencial teórico e metodológico em investigações filosóficas, antropológicas e literárias. Como expusemos acima, dado que a chave para a compreensão da metafísica bachelardiana é um projeto materialista do logos, o objetivo deste artigo é evidenciar, discutir e sistematizar a relação dialógica entre as configurações da imaginação poética pensadas por Bachelard e o simbolismo dos elementos materiais, com a finalidade de instrumentalizar -senão, ao menos, sensibilizar- pesquisadores brasileiros para esta vertente menos conhecida e pouco utilizada da filosofia de Bachelard. Lembremos que a configuração materialista (tetra-elementar) da metafísica bachelardiana -que este artigo pretende desvelarevidencia uma alternativa hermenêutica à lógica dissociativa do paradigma moderno, responsável pela equivocada disjunção entre racionalidade e imaginação simbólica, que começa a ser questionada e revista na contemporaneidade.

Água, ar e terra: expressões do "fac fixum volatile" alquímico

Seguindo uma ordem cronológica, o substancialismo que

\footnotetext{
3 Segundo Roger (1991, p. 88), o "fac fixum volatile", consiste em uma recomendação dos alquimistas para etapa de "conversão dos elementos", e pode ser lido tanto no sentido de "faça fixo o volátil", como "faça volátil o fixo", na medida que não se pode fixar um, sem volatilizar o outro, isto é, "corporificar o espírito" sem "espiritualizar o corpo". Como iconografia desta relação dialógica fixovolátil, o Caderno CICE de Ensino e Pesquisa (2000, p. 5) aponta a imagem do grifo, utilizada pelo alquimista Jérôme Marneuf (Paris, 1557): animal fabuloso híbrido de águia (elemento aéreo: razão) e leão (elemento terrestre: sensibilidade) que sustenta um bloco de pedra (expressão do real) e o globo feérico e alado de Hermes (expressão do imaginário).
}

Educ. e Filos., Uberlândia, v. 20, n. 39, p. 39-70, jan./jun. 2006. 
estrutura a vertente noturna da filosofia de Bachelard, se revela, em primeiro lugar, pelo conceito de imaginação material. É através da sua primeira obra sobre metafísica da imaginação poética, em "A água e os sonhos" de 1942, que Bachelard lança seu projeto materialista do devaneio poético, o que dará subsídios para desdobramentos futuros sobre quatro outras configurações da imaginação poética: "o imaginário não encontra suas raízes profundas e nutritivas nas imagens, a princípio ele tem necessidade de uma presença mais próxima, mais envolvente, mais material" (BACHELARD, 1998, p.126).

Assim, a primeira configuração da imaginação poética que subsidia as demais é a imaginação material, modo de expressão do devaneio poético que propõe uma mediação substancialista do sujeito com seu mundo: "a imaginação é devolvida à sua função vital que é valorizar as trocas materiais entre o homem e as coisas" (BACHELARD, 1990a, p. 51), assumindo a função de materializar, dar suporte, axializar, concretizar, corporificar o devaneio poético:

Permitimo-nos lembrar aqui alguns livrinhos recentes em que estudamos, sob o nome de imaginação material essa espantosa necessidade de "penetração" que, para além das seduções da imaginação das formas, vai pensar a matéria, sonhar a matéria, viver na matéria, ou então -o que vem dar no mesmomaterializar o imaginário. (BACHELARD, 2001c, p.7-8)

Neste sentido de "materializar o imaginário", lembrando a polaridade "faça fixo o volátil" do "fac fixum volatile", ou, coagular o devaneio poético, lembrando o "solve et coagula" alquímico, é que melhor se compreendem as imagens utilizadas por Bachelard para explicar sua noção de imaginação material. Trata-se de lembrar que o poeta, da mesma forma que o artífice, necessita da matéria para objetivar sua ação. Daí que, através do conceito de imaginação material, a caligrafia do poeta vem lembrar, por extensão dos seus devaneios materialistas, a mão trabalhadora do artífice sobre a matéria: "imagens da matéria, imagens diretas da matéria. A vista lhe dá nome, mas a mão as conhece. Uma alegria 
dinâmica as maneja, as modela, as torna mais leves" (BACHELARD, 1998, p. 2).

Assim, com o conceito de imaginação material, Bachelard vai pontuar um divisor de águas em relação às obras anteriores sobre epistemologia da ciência, assinalando a transição da vertente diurna para o delineamento noturno de sua filosofia. É assim que a diferenciação entre imaginação de causa material, que dá subsídios à penetração do substancialismo no devaneio poético, e a imaginação formal, que constitui o materialismo racional das ciências experimentais, aparece logo no início de "A água e os sonhos":

Expressando-nos filosoficamente desde já, poderíamos distinguir duas imaginações: uma imaginação que dá vida à causa formal e uma imaginação que dá vida à causa material; ou, mais brevemente, a imaginação formal e a imaginação material. (BACHELARD, 1998, p. 1)

A imaginação formal, valorizando os modelos teóricomatemáticos e a formalização lógico-empírica das ciências naturais, remete à tradição aristotélica, cartesiana e positivista de ciência. Já a imaginação material, obscurecendo a vigilância epistemológica -a repressão das imagens inconscientes-imprescindível à atividade científica, instaura os devaneios noturnos da matéria, fundando a primeira configuração substancialista da imaginação poética na metafísica de Bachelard:

Quando um devaneio, quando um sonho vem assim absorverse numa substância, o ser inteiro recebe dele uma estranha permanência. O sonho adormece. O sonho estabiliza-se. Tende a participar da vida lenta e monótona de um elemento. Tendo encontrado seu elemento, vem fundir nele todas as suas imagens. Materializa-se. Cosmotiza-se. (BACHELARD, 1998, p. 93)

A recomendação aqui é suficientemente clara para que se compreenda a função da substância ou do elemento na metafísica

Educ. e Filos., Uberlândia, v. 20, n. 39, p. 39-70, jan./jun. 2006. 
de Bachelard: materializar significa garantir permanência, dar estabilidade às imagens poéticas, isto é, "fac fixum volatile", fazer fixo o volátil. Mas é preciso assinalar que a outra polaridade do "fac fixum volatile", o "faça volátil o fixo", também é lembrada por Bachelard. Sempre ironizando com ambivalências, à semelhança do que representavam os quatro elementos materiais para os alquimistas, a materialização do devaneio não se realiza por uma matéria real:

Não se deveria, porém, vincular tal classificação das inspirações poéticas a uma hipótese mais ou menos materialista que pretendesse encontrar na carne dos homens um elemento material predominante. Não se trata em absoluto de matéria, mas de orientação. Não se trata de raiz substancial, mas de tendências, de exaltação. (BACHELARD, 1999b, p. 133)

Admitindo a intangibilidade do projeto materializador através dos quatro elementos, Bachelard procede à sutilização do impulso materializante da imaginação material. Temendo "imobilizar-se", "solidificar-se", "cristalizar-se", a imaginação material abandona a pesada carga de materialidade para se eufemizar em "uma tendência", uma diretriz condutora do devaneio poético. Então, os elementos materiais vão representar mais uma função reguladora e organizadora da imagem, do que, propriamente, se constituírem em uma matéria que estrutura o devaneio:

Não estamos em erro, acreditamos, ao caracterizar os quatro elementos como hormônios da imaginação. Eles põem em ação grupo de imagens. Ajudam a assimilação íntima do real disperso em suas formas. Por eles se efetuam as grandes sínteses que dão características um pouco regulares ao imaginário. (BACHELARD, 2001c, p. 12)

A associação "elemento-hormônio" se explica porque um hormônio agindo em baixíssimas doses, portanto, diluído de sua materialidade, mantém, ainda assim, sua potência de ação, 
desempenhando uma função homeostática, isto é, auto-reguladora, que mantém o equilíbrio dinâmico do organismo. A metáfora "matéria-hormônio" não estaria referindo a primazia da função homeostática -auto-reguladora- do elemento, ainda que diluído de sua materialidade, na estruturação do devaneio poético? Volatiliza-se, assim, a "materialidade" do elemento material, de modo que, para além de se apresentarem como matéria que fixa, concretiza e coagula, os elementos, "desmaterializados", serão "operadores de imagens" (BACHELARD, 1989, p. 9). Aliviando o excesso de "peso" que pode sufocar a dinâmica do devaneio, a imaginação material de Bachelard alcança o outro pólo do "fac fixum volatile", no sentido de "faça volátil o fixo".

Assim é possível mostrar que é através da dialógica situada pelo "fac fixum volatile" que melhor se compreende a primeira configuração da imaginação poética representada pela imaginação material bachelardiana. Esta, vivendo a meio caminho entre o devaneio materializado pela matéria ("faça fixo o volátil") e a matéria volatilizada pelo devaneio do sujeito imaginante ("faça volátil o fixo"), circunscreve uma mediação entre o "fixo-volátil", "matéria-devaneio" e "sujeito-mundo". Aqui é importante perceber que, se a imaginação material prescreve uma tensão de forças entre volatilidade e fixação; então, nada mais alquímico do que apresentá-la, conceitualmente, sob a égide do elemento transitório: a água. Declaradamente, "a água é realmente o elemento transitório. É a metamorfose ontológica essencial entre o fogo e a terra" (BACHELARD, 1998, p. 7).

A meio caminho entre a materialidade compacta da terra e a sutilidade dos elementos leves como o fogo e o ar, a água vai dar o mote simbólico para que o conceito de imaginação material -que pressupõe também ele, uma imagem dialógica de "fixaçãovolatilização"- seja desenvolvido na obra "A água e os sonhos". Esta ambivalência da materialidade da água -"fluida, sua tendência é a dissolução; mas homogênea também, ela é igualmente o símbolo da coesão, da coagulação" (CHEVALIER, 2000, p. 15)representa justamente o "solve et coagula", ou, o "fac fixum volatile" em que Bachelard se baseia, tacitamente, para conceituar sua noção

Educ. e Filos., Uberlândia, v. 20, n. 39, p. 39-70, jan./jun. 2006. 
de imaginação material. Aliás, como é objetivo deste artigo mostrar, é esta opção por um cogito alquimizado -isto é, que parte do arquétipo dos quatro elementos, para postular configurações da imaginação poética- que funda o estilo da metafísica bachelardiana:

Para estudar esse cogito valorizante, como são úteis as dialéticas extremas de enriquecimento e de libertação tais como as que sugerem as imaginações terrestre e aérea, das quais uma sonha nada perder e a outra tudo dar! (BACHELARD, 2001c, p. 269)

Surrealizando a expressão cartesiana "cogito ergo sum" (penso, logo existo) em "materializo, logo penso", entendemos que o fragmento acima evidencia um dos principais objetivos deste artigo: mostrar que por trás de cada estrutura do cogito -aqui entendido como configuração da imaginação poética- há, na metafísica bachelardiana, uma matéria, o que dá no mesmo dizer que, em decorrência das propriedades da matéria, Bachelard destacará uma configuração do cogito. Assim, a imaginação material, corporificada pela transitoriedade do elemento água, realiza a conciliação dos pólos "fixação" (elemento terra) e "volatilização" (elemento ar) do "fac fixum volatile", apresentandose como a primeira configuração da imaginação poética, cuja estruturação materialista, vai subsidiar os quatro tipos seguintes.

É assim que o projeto materialista, iniciado em "A água e os sonhos", vai se estender com o conceito de imaginação dinâmica, que se nutrirá do exagero do "fac fixum volatile", de modo que, com o elemento ar, haverá uma polarização no sentido de uma volatilização que perde de vista a fixação, e, inversamente, com o elemento terra, haverá uma compactação do devaneio que, ao enrijecer a matéria, atrairá para si a cólera do sonhador. Esta relação dialógica "cogito-elemento-material", agora situando a terra e o ar, aparece representada, novamente, no fragmento:

Parece que, para a imaginação terrestre, dar é sempre abandonar, tornar-se leve é sempre perder substância, 
gravidade. Mas tudo depende do ponto de vista: o que é rico em matérias, quase sempre é pobre em movimentos. Se a matéria terrestre, em suas pedras, em seus sais, em seu metal é o sustentáculo de riquezas imaginárias infinitas, ela é dinamicamente o mais inerte dos sonhos. Ao ar, ao fogo aos elementos leves- pertencem, ao contrário, as exuberâncias dinâmicas. (BACHELARD, 2001c, p. 269)

É sob a égide do elemento aéreo, precisamente representado na obra "O ar e os sonhos", que Bachelard procede à valorização extremada da desmaterialização, re-significando sua imaginação material em imaginação do movimento, criando, assim, a segunda configuração do seu projeto materialista da imaginação poética. Distendendo o pólo "fac fixum volatile" em direção à volatilização, a materialidade do ar, se evola em dinamismo: "a imaginação substancial do ar só é verdadeiramente ativa numa dinâmica de desmaterialização" (BACHELARD, 2001c, p. 165). Então, vencida pela sedução de leveza, a imaginação material do ar cede lugar à imaginação dinâmica: "o ar é uma matéria pobre. Em compensação, porém, com o ar teremos uma grande vantagem, referente à imaginação dinâmica. Efetivamente, com o ar o movimento supera a substância. Não há substância senão quando há movimento" (BACHELARD, 2001c, p. 9).

É através da desmaterialização promovida pelo mais leve dos elementos, que encontraremos definida uma primeira concepção da imaginação dinâmica bachelardiana, o que constitui o segundo modo de expressão da imaginação poética. Parece-nos que a imaginação dinâmica é um prolongamento da imaginação material, que excede seu equilíbrio, levando, ao extremo, a volatilização. Contrariando a função da imaginação material que é a de "materializar o imaginário", a imaginação dinâmica da obra "O ar e os sonhos", em um salto quântico, estirando o pólo da volatilidade, abandona a função materializadora de imagens. $\mathrm{Na}$ verdade, trata-se de uma revolução copernicana: as imagens não são materializadas pela matéria na noção de imaginação dinâmica, mas, ao contrário, o movimento cria a imagem: "a imaginação

Educ. e Filos., Uberlândia, v. 20, n. 39, p. 39-70, jan./jun. 2006. 
dinâmica ganha então a dianteira sobre a imaginação material. $\mathrm{O}$ movimento imaginado, desacelerando-se, cria o ser terrestre; o movimento imaginado, acelerando-se, cria o ser aéreo" (BACHELARD, 2001c, p. 109).

Estamos aqui, novamente, frente à potência elementar, que comanda a proposição do cogito: para a água, elemento materialmente intermediário, valoriza-se a matéria, temos a imaginação material; quando o movimento supera a matéria, o que se dá com o ar, temos a imaginação dinâmica. Assim, a imaginação dinâmica vivendo do movimento, produz a imagem: "na imaginação dinâmica, tudo se anima, nada se detém. O movimento cria o ser, o ar turbilhonante cria as estrelas, o grito produz imagens, o grito gera a palavra, o pensamento" (BACHELARD, 2001c, p. 233).

Esta perspectiva que vai do movimento à materialização da imagem, atribuída por Bachelard à imaginação dinâmica, apesar de melhor explicitada para o elemento aéreo, já aparece representada em " $A$ água e os sonhos". Nesta obra, o movimento da água sobre as pedras de um riacho raso de águas turbulentas, traz imediatamente a imagem da cabeleira flutuante da mulher afogada, imagem que Bachelard associa ao complexo de Ofélia ${ }^{4}$, por identificação à Ofélia afogada de Hamlet:

Insistamos um pouco mais nessa característica dinâmica da imaginação, característica dinâmica à qual esperamos dedicar um outro estudo. No tema que estamos desenvolvendo, fica muito claro que não é a forma da cabeleira que faz pensar na água corrente, mas o seu movimento. A cabeleira pode ser a de um anjo do céu; no momento em que ondula ela traz naturalmente sua imagem aquática. (BACHELARD, 1998, p. 88)

${ }^{4} \mathrm{Na}$ perspectiva bachelardiana, a imagem literária é um universo imagético híbrido entre a pregnância cultural (imperativo sócio-cultural) e a ressonância da subjetividade materialista do poeta (imperativo materialista tetraelementar). À guisa desta concepção bidimensional de imagem literária, o 
Cabeleira e água reunidas em analogia à "ondulação", isso porque, à beira do riacho, a água que ondula é uma cabeleira. É por meio deste dinamismo da fluidez aquática, que Shakespeare encontra na água, o elemento para materializar o suicídio da amada de Hamlet, criando na perspectiva de Bachelard, o complexo de Ofélia.

Nas obras dedicadas ao elemento fogo, a imaginação dinâmica vai se manifestar através do movimento verticalizante, de um impulso de verticalidade. É assim que em "A chama de uma vela", a chama será guia para as imagens ascensionais: "a meditação da chama deu ao psiquismo do sonhador uma alimentação de verticalidade, um alimento verticalizante. Uma alimentação aérea, sendo o oposto de todas as 'alimentações terrestres'" (BACHELARD, 1989, p. 12). Já na obra "Fragmentos de uma poética do fogo", a valorização do dinamismo do elemento ígneo suscita a imagem dos pássaros de fogo, da qual a mitológica Fênix é um exemplo privilegiado de materialização pelo movimento:

Todas essas imagens que queremos examinar antes de considerar as imagens mais propriamente ligadas à imagem tradicional da fênix são imagens dinâmicas. Não são

determinante cultural da imaginação poética dá origem ao que Bachelard chamou de complexo de cultura: "não hesitaremos, pois, em chamar complexos novos por seu signo cultural, pelo signo que todo homem culto reconhece" (BACHELARD, 1998, p. 20). Estes complexos de cultura aparecem organizados por referência às personagens de narrativas míticas, como por exemplo, o complexo de Prometeu (1999b, p. 11-19; 1990b, p. 89-112), o complexo de Empédocles (1999b, p. 21-31; 1990b, p. 113-142), o complexo de Narciso (1998, p. 23-25), o complexo de Caronte (1998, p. 79), o complexo de Sísifo (2001b, p. 155), o complexo de Medusa (2001b, p. 168), o complexo de Atlas (2001b, p. 286-294), o complexo de Jonas (1990a, p. 101-139) e o complexo de Laocoonte (1990a, p. 216-221). Há também referência dos complexos de cultura às personagens literárias, como por exemplo, o complexo de Ofélia (1998, p. 82-90) e o complexo de Harpagon (1999a, p. 164, 172-177). Por fim, a referência ao signo cultural aparece em relação ao poeta e nadador Swinburne, através do complexo de Swinburne (1998, p. 169-178), e, em relação à obra de Novalis, através do complexo de Novalis (1999b, p. 33-63).

Educ. e Filos., Uberlândia, v. 20, n. 39, p. 39-70, jan./jun. 2006. 
verdadeiramente imagens de substâncias. Os pássaros de fogo não são imagens da substância do fogo, são imagens da rapidez. (BACHELARD, 1990b, p. 54)

Em seu estilo gracioso e entusiasmado, Bachelard não tarda a sobrepujar a imaginação material pela imaginação dinâmica: "é o movimento, mais que a substância que é imortal em nós" (BACHELARD, 2001c, p. 47). Acostumados à liberdade estilística de Bachelard, vislumbramos a imaginação dinâmica, tanto quanto a imaginação material, como "operadoras de imagens". Chegamos assim a um novo modo de expressão da imaginação que responde ao movimento, mais do que à matéria.

Mas vejamos que este estilo descomprometido com o risco de contradição faz com que Bachelard considere uma segunda concepção de imaginação dinâmica, que obedecendo aos determinantes opostos da fluidez aérea, constituirá a terceira configuração do projeto materialista da imaginação poética de Bachelard. De fato, em termos físicos, enquanto a cinemática estuda o movimento -que se relaciona à imaginação dinâmica de "O ar e os sonhos"- é a dinâmica, propriamente dita, que estuda o movimento dos corpos relacionando-o às forças que o produzem. É através do "livro dinâmico" -metáfora utilizada por Bachelard (1990a, p. 134) para caracterizar a obra "A terra e os devaneios da vontade" - que uma filosofia dinâmica vai fazer jus ao sentido físico do termo, ao evidenciar a imaginação das forças. É assim que, sob a égide da força do homem e de sua gana de transformar a matéria, se revela a real perspectiva dinâmica: "no reino da imaginação, pode-se dizer da mesma forma que a resistência real suscita devaneios dinâmicos ou que os devaneios dinâmicos vão despertar uma resistência adormecida nas profundezas da matéria" (BACHELARD, 2001b, p. 20).

No caminho de uma filosofia alquimizada pela correspondência entre as idéias e os simbolismos da matéria, Bachelard escolhe a resistência do elemento terra para desenvolver seu novo conceito de imaginação dinâmica: 
A terra, com efeito, ao contrário dos outros três elementos, tem como primeira característica uma resistência. Os outros elementos podem ser hostis, mas não são sempre hostis. A resistência da matéria terrestre, pelo contrário, é imediata e constante. (BACHELARD, 2001b, p. 8)

É pela solidez e pela dureza do "mais material" dos elementos, do mais resistente às forças humanas, e, portanto do mais provocativo, que Bachelard desenvolve sua outra concepção de imaginação dinâmica: "não nos enganemos: o adversário que insulta não é necessariamente um homem -as próprias coisas nos questionam. Em compensação, em sua experiência audaciosa, o homem brutaliza o real" (BACHELARD, 1998, p. 167). Notemos que a adversidade não é necessariamente um fato real, isso porque, a imaginação dinâmica, hiperbolizando as adversidades do mundo, aumenta o poder de provocação do elemento material: "para a imaginação dinâmica há, além da coisa, a supercoisa" (BACHELARD, 2001b, p. 32). Em certo sentido, a imaginação dinâmica, colocando a tônica no poder provocante do meio, na hipérbole das suas adversidades, traz à tona a dinamogenia, a cólera do homem contra o adversário material que o provoca:

Compreendo o mundo porque o surpreendo com minhas forças incisivas, com minhas forças dirigidas, na exata hierarquia de minhas ofensas, como realizações de minha alegre cólera, de minha cólera sempre vitoriosa, sempre conquistadora. (BACHELARD, 1998, p. 166)

Esta segunda versão da imaginação dinâmica se apresenta como exaltação ativa, ofensiva, colérica do sonhador excitado por um mundo super provocativo, muito adverso. Neste caso, aparece como sinônimo de imaginação dinâmica, o termo dinamogenia, mostrando que a origem desta exaltação é mediada pela imaginação das forças do sonhador. Assim, se na concepção de imaginação material, a matéria intermediava a relação sujeito-ambiente, nesta versão da imaginação dinâmica, a intermediação é realizada pela

Educ. e Filos., Uberlândia, v. 20, n. 39, p. 39-70, jan./jun. 2006. 
cólera do sonhador: "a cólera é a mais direta das transações entre o homem e as coisas" (BACHELARD, 1998, p. 184).

Situando a adversidade do mundo, o "trabalho-com-amatéria" ${ }^{5}$ representará uma ação da imaginação dinâmica. Veremos, então, evidenciar-se na metafísica poética bachelardiana, o antigo sonho demiúrgico do homo faber:

O mundo resistente nos impulsiona para fora do ser estático, para fora do ser. E começam os mistérios da energia. Somos desde então seres despertos. Com o martelo ou a colher de pedreiro na mão, já não estamos sozinhos, temos um adversário, temos algo a fazer. (BACHELARD, 2001b, p. 16)

A imaginação dinâmica é, assim, o impulso criador que mobiliza a energia para o trabalho material pela mão do homem. Cavando a terra, furando a pedra, ou, entalhando a madeira, o homo faber quer trabalhar a matéria, quer transformá-la. É no trabalho contra a matéria, nesta fenomenologia do trabalho manual, que vamos encontrar a "mão dinâmica" do sonhador. A matéria resistente provoca, dá ao trabalhador a consciência de sua força. É neste existencialismo da força, que Bachelard corporifica a segunda versão de imaginação dinâmica: "a consciência do trabalho se precisa simultaneamente nos músculos e nas articulações do trabalhador e nos progressos regulares da tarefa. Assim, a luta do trabalho é a mais cerrada das lutas" (BACHELARD, 2001b, p. 18-19).

Sistematizando o que dissemos, a imaginação dinâmica associada à terra é uma implicação da imaginação muscular, isso porque, o alongamento das fibras musculares no desempenho do

${ }^{5}$ Esta concepção de trabalho material se refere às atividades realizadas pelo contato da mão com a matéria, remetendo à provocação induzida pelo elemento terrestre: "Parece que as matérias terrestres, assim que as pegamos com a mão curiosa e corajosa, excitam em nós a vontade de trabalhá-las. Acreditamos portanto poder falar de uma imaginação ativista" (BACHELARD, 1990a, p. 1). 
"trabalho-com-a-matéria", exige uma matéria dura; tanto mais provocativa será, quanto mais dura for ao devaneio do trabalhador. É então que a dureza do elemento terra é provocação: "para um sonhador da dureza íntima, o granito é um tipo de provocação" (BACHELARD, 2001b, p. 18).

Assim, invertendo a tendência da imaginação dinâmica -o melhor seria "cinemática"- de "O ar e os sonhos", que distende a polaridade "fac fixum volatile" no sentido da volatilização, a imaginação dinâmica de "A terra e os devaneios da vontade" polariza a fixação, engendrando a terceira configuração da imaginação poética na metafísica de Bachelard. A fixação agregando matéria a matéria, torna-a mais densa, mais dura. É pela dureza que a matéria torna-se ofensiva e atiça a musculatura do sonhador.

Salientemos que este modo de solicitação dinâmica não poderia se dar pelo ar, ou pelo fogo, elementos leves e voláteis. O enfrentamento a estes elementos leves seria um ato de covardia que não receberia a mobilização da energia tonificante e renovadora necessária à criação de imagens: "contra o vento o combate é quase sempre sem derrota. Um herói do vento que fosse derrubado por uma rajada seria o mais ridículo dos generais vencidos" (BACHELARD, 1998, p. 168). O elemento que dá certeza de vitória não provoca, não incita a cólera, explicando a necessidade da matéria terrosa para que a outra concepção de imaginação dinâmica "brutalize o real". Assim, em "A terra e os devaneios da vontade", se configura o terceiro modo de expressão da imaginação poética através da representação de imagens da cólera, do trabalho duro, das adversidades hiperbolizadas do mundo.

Inaugurando o projeto materialista da imaginação poética, a obra "A água e os sonhos" -orientada pelas pregnâncias simbólicas da água, elemento de materialidade transitória- vai lançar, mas não desenvolver, os dois tipos de imaginação dinâmica que expusemos. Assim, para além da imaginação do movimento, da ondulação da água que materiliza a cabeleira, e, conseqüentemente, o afogamento da Ofélia de Hamlet, esta obra traz a concepção de imaginação dinâmica ligada à experiência

Educ. e Filos., Uberlândia, v. 20, n. 39, p. 39-70, jan./jun. 2006. 
muscular do nado no mar, motivo que, segundo Bachelard, inspirou a poética de Swinburne:

Nosso último capítulo não será propriamente um estudo da imaginação material, mas um estudo da imaginação dinâmica, à qual esperamos dedicar outra obra. O capítulo intitula-se A água violenta. (...) Mostraremos a vontade de ataque que anima o homem que nada, depois a desforra da onda, o fluxo e o refluxo da cólera que ribomba e repercute. (...) Este será um novo exemplo do organicismo fundamental da imaginação. Reencontraremos assim a imaginação muscular. (BACHELARD, 1998, p. 16)

Retomando nosso objetivo inicial, é preciso insistir que é partindo das ressonâncias arquetípicas da água, do ar e da terra na formulação das três configurações da imaginação poética: 1) imaginação material, 2) imaginação dinâmica do movimento e 3) imaginação dinâmica das forças ou dinamogenia, que iremos provar o estilo alquimizado da metafísica bachelardiana. Aliás, é esta possibilidade de organizar a imaginação material e as duas concepções de imaginação dinâmica, a partir das imagens alquímicas da volatilização e da fixação -suscitadas, elas mesmas, pelos simbolismos da materialidade da água, da terra e do ar-que explica porque partimos da dialógica do "fac fixum volatile" para desenvolver esta seção.

\section{A terra e o fogo: duplicações da imaginação do repouso}

Bachelard não se dá por satisfeito com a representação do elemento terra em "A terra e os devaneios da vontade", e, no mesmo ano de publicação desta obra, em 1947, publica "A terra e os devaneios do repouso", resgatando o princípio feminino, intimista e obscuro do elemento terra, escamoteados frente à rigidez material situada na obra anterior. Então, o elemento terra recebe uma valorização concorrente e complementar às imagens que se desenharam nos devaneios ativistas de "A terra e os devaneios da vontade": 
Pode-se sentir em ação, em muitas imagens materiais da terra, uma síntese ambivalente que une dialeticamente o contra e o dentro, e mostra uma inegável solidariedade entre os processos de extroversão e os processo de introversão. (BACHELARD, 1990a, p. 2)

Se o primeiro livro sobre o elemento terra -"A terra e os devaneios da vontade" - foi escrito sob a preposição "contra", para assinalar o devaneio dinâmico e ativista, o segundo, "A terra e os devaneios do repouso", é escrito sob signo introvertido da preposição "dentro". Assim é que a inversão conceitual, própria ao estilo bachelardiano, defenderá na segunda obra sobre o elemento terra, as imagens da intimidade ${ }^{6}$ : "mostraremos que toda matéria imaginada, toda matéria meditada, torna-se imediatamente a imagem de uma intimidade" (BACHELARD, 1990a, p. 3). É através dos princípios feminino, passivo e maternal, atribuídos, arquetipicamente, ao elemento terra, que Bachelard inverte a imaginação dinâmica em imaginação do repouso:

É ao sonhar com essa intimidade que se sonha com o repouso do ser, com um repouso enraizado, um repouso que tem intensidade e que não é apenas essa imobilidade inteiramente externa reinante entre as coisas inertes. É sob a sedução deste repouso íntimo e intenso que algumas almas definem o ser pelo repouso, pela substância, em sentido oposto ao esforço que fizemos, em nossa obra anterior, para definir o ser humano como emergência e dinamismo. (BACHELARD, 1990a, p. 4)

6 Bachelard dá prosseguimento à investigação das imagens da intimidade, não mais tomando por referência a imaginação dos quatro elementos, mas uma topoanálise -"estudo psicológico sistemático dos locais de nossa vida intima" (BACHELARD, 2000, p. 28)- em A poética do espaço: "É à região de intimidade, à região cujo peso psíquico é dominante, que dedicamos as nossas pesquisas" (BACHELARD, 2000, p. 31).

Educ. e Filos., Uberlândia, v. 20, n. 39, p. 39-70, jan./jun. 2006. 
Apesar de uma aparente antinomia entre "repouso" e "dinâmico", a imaginação do repouso bachelardiana não é uma recomendação de descanso da atividade criadora da imaginação poética. Ao contrário, este repouso vai dimamizar a imaginação, suscitando imagens através da desaceleração do tempo, trazendo a alegria da lentidão de volta à imaginação do sonhador. É exagerando a desaceleração do tempo, que a imaginação do repouso vai incitar o devaneio:

O lento não é o rápido freado. O lento imaginado também quer o seu excesso. O lento é imaginado num exagero da lentidão, e o ser imaginante usufrui não a lentidão, mas o exagero da desaceleração. Vejam como os seus olhos brilham, leiam no seu rosto a alegria fulgurante de imaginar a lentidão, a alegria de desacelerar o tempo, de impor ao tempo um futuro de suavidade, de silêncio, de quietude. (BACHELARD, 2001b, p. 22)

Quem nunca sentiu um bem-estar detendo, imageticamente, a foice de Cronos? A imaginação do repouso bachelardiana parece devolver a paz do tempo vertical, do tempo sem-tempo, do tempo suspenso do caos primordial. É por esta satisfação de um tempo que não segue a medida do relógio -tempo vertical- que a imaginação do repouso instiga a imaginação.

Mas há uma condição sine qua non para o exercício da imaginação do repouso: o sonhador precisa se sentir confortável e seguro, para que se inverta o sentido adverso dado ao mundo pela imaginação dinâmica. Na filosofia alquimizada de Bachelard, que dá concretude às idéias pelo lastro de materialidade elementar, nenhum elemento supera o bem-estar do fogo-calor: "a primeira convicção calorosa é um bem-estar corporal. É na carne, nos órgãos, que nascem as imagens materiais primordiais" (BACHELARD, 1998, p. 9).

Meditando sobre esta "primeira convicção calorosa", fechemos os olhos e tentemos lembrar da nossa mais antiga sensação de bemestar. Se o tempo se verticalizasse o suficiente, será que não encontraríamos, no fundo da nossa alma, a quentura alegre do 
primeiro fogo acendido e conservado pela humanidade? É o alento térmico do fogo, este "calórico" por tanto tempo imponderável para ciência racionalista e objetiva, que vai animar a imaginação do repouso e, assim, estimular a imaginação poética. A tal ponto é o amor de Bachelard pelo fogo, que o frio não encontra espaço em sua metafísica alquimizada. Diferentemente da "consciência profunda da felicidade calorífica" (BACHELARD, 1999b, p. 61), o frio é antítese do bem-estar do homem que revive os sonhos dos "primeiros fogos" da civilização:

Apesar de muitas pesquisas, não conseguimos até agora constituir um dossiê suficiente para estudar objetivamente a imaginação do frio. Lemos inutilmente muitas narrativas sobre viagens polares sem em geral encontrar outros meios de evocar o frio a não ser uma referência -inteiramente racionalizada, não resta dúvida- ao termômetro. $\mathrm{O}$ frio, em nossa opinião, é uma das maiores proibições da imaginação humana. (BACHELARD, 1990a, p. 204)

O frio do homem abandonado, o "frio-na-barriga": representação de medo e angústia, o frio da alma no instante da morte, o frio da humanidade congelada no inverno... quantas razões arquetipais para combatê-lo! Baseado nesta singularidade atribuída por Bachelard às imagens do fogo encontraremos a quarta configuração da imaginação poética que deriva do bem-estar espaço-temporal dos devaneios do repouso, pela contemplação da chama da vela:

Existe um parentesco entre a lamparina que vela e a alma que a sonha. Tanto para uma quanto para a outra o tempo é lento. Então o tempo se aprofunda, as imagens $\underline{\text { e }} \underline{\text { as }}$ lembranças se reúnem. O sonhador inflamado une o que vê ao que viu. Conhece a fusão da imaginação com a memória. Abre-se então a todas as aventuras da fantasia, aceita a ajuda dos grandes sonhadores e entra no mundo dos poetas. (BACHELARD, 1989, p. 19, grifos meus)

Educ. e Filos., Uberlândia, v. 20, n. 39, p. 39-70, jan./jun. 2006. 
À deriva, na meditação confortável da imaginação do repouso, no instante em que o tempo se verticaliza, há reunião da imagem que se "vê" com a lembrança que se "viu" -que grafaremos como "imagem-lembrança"- para assinalar a fusão. Respondendo às ambivalências da imagem no presente e da imagem na memória, a imagem-lembrança representará o quarto tipo de expressão da imaginação poética, criando imagens por repercussão da lembrança. Apesar de mais velada que as outras configurações que apresentamos, há em diferentes obras de Bachelard, argumentos para situar a imagem-lembrança como promotora de imagens:

A casa, como o fogo, como a água, nos permitirá evocar, na seqüência de nossa obra, luzes fugidias de devaneio que iluminam a síntese do imemorial com a lembrança. Nessa região longínqua, memória e imaginação não se deixam dissociar. Ambas trabalham para seu aprofundamento mútuo. Ambas constituem, na ordem dos valores, uma união da lembrança com as imagens. (BACHELARD, 2000, p. 25)

É através da mestiçagem entre a imagem atual e as do passado do sonhador, através da imagem-lembrança, que a linguagem poética recebe mais um impulso para criar imagens: "o homem mira-se em seu passado, toda imagem é para ele uma lembrança" (BACHELARD, 1998, p. 69). Mas, se a imagem-lembrança é inspirada pela memória, em que "passado" Bachelard posiciona o jorro de lembranças do homem? Suzanne Bachelard, organizadora da última obra inacabada do pai, "Fragmentos de uma poética do fogo", ajuda a esclarecer a questão:

Podemos notar em seus livros inúmeras evocações da infância. Essas evocações são o signo, não de uma nostalgia de um estado de infância, de uma nostalgia da inocência, mas, sim, da nostalgia das capacidades de maravilhamento da criança sonhadora e livre, e também capacidade de aprender e se transformar. (BACHELARD, 1990b, p. 16) 
Bachelard também confirma, várias vezes em sua obra, as intuições da filha sobre a máxima apreensão imagética do mundo durante a infância: "foi dito freqüentemente que a criança reunia todas as possibilidades. Crianças éramos pintor, modelador, botânico, escultor, arquiteto, caçador, explorador. E o que aconteceu com tudo isso?" (BACHELARD, 2001b, p. 76). Seja pela capacidade de entrega ao maravilhamento, ou, pelas possibilidades ilimitadas de apreender, a infância será para Bachelard o período magno da existência humana: "no trajeto que nos leva de volta às origens, há primeiramente o caminho que nos restitui à infância, à nossa infância sonhadora que desejava imagens, que desejava símbolos para duplicar a realidade" (BACHELARD, 1990a, p. 94). Portanto, se há reserva de imagens nas memórias da infância, e se a imagem pode ser gerada pela repercussão da lembrança, entendese porque "comunicamo-nos através de nossas infâncias" (BACHELARD, 2001b, p. 79).

Assim, através do conceito de imagem-lembrança de Bachelard, o verbo recordar (do latim "re-cord-ari") revive seu sentido etimológico de recorrer ao coração (do latim "cor", "cordis"), para nele avivar nossas memórias; afinal, nossas lembranças mais íntimas, não as lembramos "pelo" e "de" coração? Mas se a lentidão do devaneio do repouso, se a manifestação do tempo vertical perde-se em sua contagem -distende-se arqueologicamente- eis que um outro "operador de imagens", que vive em um passado bem mais remoto do que a infância, emerge da imagem-lembrança:

Para nós não há nenhum passado que nos dê o gosto de nosso passado, sem que logo se torne, em nós um passado mais longínquo, mais incerto, esse passado enorme que já não tem data, que já não sabe as datas de nossa história. (BACHELARD, 1990a, p. 96)

Se uma descida ao passado pela imaginação do repouso duplicasse a escala temporal, desceríamos até a infância pela imagem-lembrança e, até os primórdios da humanidade, através

Educ. e Filos., Uberlândia, v. 20, n. 39, p. 39-70, jan./jun. 2006. 
das imagens arquetipais. Neste sentido, um mergulho no imemorial suscita a quinta configuração da imaginação poética através da ressonância na atemporalidade da imagem arquetípica, como já havia sido descrito por Jung?:

O debate que queremos encetar sobre a primitividade da imagem é imediatamente decisivo, pois vinculamos a vida própria das imagens aos arquétipos cuja atividade foi mostrada pela psicanálise. As imagens imaginadas são antes sublimações dos arquétipos do que reproduções da realidade. (BACHELARD, 2001b, p. 3)

Se as imagens poéticas são "sublimações dos arquétipos", podemos considerá-los como o quinto modo de expressão da imaginação poética. Na voz de Bachelard: "para o poeta, o objeto já é uma imagem, o objeto é um valor da imaginação. O objeto real não tem potência poética a não ser pelo interesse apaixonado que recebe do arquétipo" (BACHELARD, 1990a, p. 205).

Mas o arquétipo não é um museu de imagens do qual o sonhador se apropria e copia; ao invés disso, conforme Jung (2002, p. 58), é uma sugestão de ação ou percepção que remete a uma situação típica repetida pela humanidade, sendo, portanto, um modelo abstrato que depende da elaboração consciente para se converter em imagem arquetípica ${ }^{8}$. Assim, a concretização do

7 No decorrer de suas obras, Bachelard deixa evidente que a noção de arquétipo de que se utiliza, é de inspiração junguiana: "Para C. G. Jung, o arquétipo é uma imagem que tem sua raiz no mais remoto inconsciente, uma imagem que vem de uma vida que não é a nossa vida pessoal e que não podemos estudar a não ser reportando-nos a uma arqueologia psicológica" (BACHELARD, 1990a, p. 203).

8 O termo imagem arquetipal, que estamos utilizando, nos pareceu próprio por discernir, como pretendeu Jung, os conteúdos do inconsciente arquetípico, da sua representação: a imagem, ou, a imaginação arquetipal. A importância desta precisão de linguagem também é pontuada por Araújo (2003, p. 342): "A distinção entre arquétipo e imagem arquetípica parece-nos fundamental, porquanto são as imagens arquetípicas, presentes nas narrativas míticas, que nos dão conta da natureza do arquétipo e não o contrário. Daí afirmamos, com Charles Baudouin, que, embora à primeira vista, 
arquétipo em imagem arquetípica depende da subjetividade do sonhador, o que ratifica a potência criativa que Bachelard atribui à imaginação arquetipal: "é essa contribuição pessoal que torna os arquétipos vivos; cada sonhador repõe os sonhos antigos em uma situação pessoal. Assim se explica porque um símbolo onírico não pode receber, em psicanálise, um sentido único" (BACHELARD, 1990a, p. 174).

É assim que, pela arte do poeta, o arquétipo se transforma em imagem, ao mesmo tempo em que, a imagem recebe do arquétipo uma carga de ancestralidade que lhe dá pregnância e força psíquica: "enthusiasmós". É pelo poder do fogo em expressar ancestralidade -é por sua força mobilizadora de arquétipos- que o elemento ígneo é o leitmotiv da imaginação arquetipal:

A chama nos leva a ver em primeira mão: temos mil lembranças, sonhamos tudo através da personalidade de uma memória muito antiga e, no entanto, sonhamos como todo mundo, lembramo-nos como todo mundo se lembra -então, seguindo uma das leis mais constantes da fantasia diante da chama, o sonhador vive em um passado que não é mais unicamente seu, no passado dos primeiros fogos do mundo. (BACHELARD, 1989, p. 11, grifos meus)

Se diante da chama de uma vela, somos remetidos ao tempo dos "primeiros fogos do mundo", isto é, à memória ancestral e coletiva, é porque a ação de fricção para obtenção do fogo, repetida inúmeras vezes, não seria um dos arquétipos da cultura humana. Mobilizador da sensação de bem-estar, de proteção, de calor, de invenção, de iluminação, de partilha, de euforia, de ressonância sexual e tantos outros, o fogo se estabelece, arqueologicamente, como arquétipo. É assim que o fogo, mais do que os outros

possa parecer lógico definir o mito mediante o arquétipo, visto que ele é sua manifestação vital, o facto é que, sendo o arquétipo um elemento inconsciente, só é possível atingi-lo através das suas manifestações (...). Por outras palavras, são as imagens arquetípicas que permitem aceder ao mundo arquetipal".

Educ. e Filos., Uberlândia, v. 20, n. 39, p. 39-70, jan./jun. 2006. 
elementos, impulsiona a imaginação do repouso, incita a lassidão temporal que invade o devaneio para trazer à tona "o homem velho na criança, a criança no homem velho" (BACHELARD, 1999b, p. 6). Com esta expressão, Bachelard não se refere, respectivamente, à imaginação arquetipal e à imagem-lembrança de infância?

É através destes dois deflagradores de imagens, situados pelo arquétipo do elemento fogo, que a imaginação do repouso materializa sua presença. Assim, no extremo oposto do movimento e da provocação da imaginação dinâmica, a quietude e o bemestar do sonhador recordam seus tempos felizes de infância e os atos primordiais que acompanharam o desenvolvimento arqueológico da civilização humana, quando o fogo foi fator decisivo de evolução e sobrevivência. Então, à sombra calorosa do fogo, a solidão tranqüilizada pela verticalização do tempo, opõe o ativismo da imaginação dinâmica à introversão pela imaginação do repouso, que se duplica na quarta e na quinta configuração que evidenciamos: a imagem-lembrança e a imaginação arquetipal.

\section{Gaston Bachelard: um filósofo da imaginação ígnea}

Destacamos neste artigo cinco configurações da imaginação poética que delimitamos na metafísica de Bachelard: 1) imaginação material, 2) imaginação dinâmica do movimento, 3) imaginação dinâmica das forças, 4) imagem-lembrança e 5) imaginação arquetipal, tentando relacioná-las ao arquétipo dos quatro elementos que lhes servem de mote simbólico. Por fim, para provarmos a co-dependência entre os cinco modos de expressão de imaginação poética e o simbolismo dos quatro elementos, é preciso mostrar que esta pregnância tetra-elementar é vivida e confessada pelo próprio Bachelard, através das suas imagenslembrança de infância. Assim, em relação à água:

Nasci numa região de riachos e rios, num canto da Champagne povoado de várzeas, no Vallage (...) Sonhando perto do rio, consagrei minha imaginação à água, à água verde e clara, à água que enverdece os prados. Não posso

Educ. e Filos., Uberlândia, v. 20, n. 39, p. 39-70, jan./jun. 2006. 
sentar perto de um riacho sem cair num devaneio profundo, sem rever a minha ventura... (BACHELARD, 1998, p. 8-9).

Nascendo e vivendo impregnado pela paisagem inundada da várzea, o elemento água, elemento do tempo de infância, vai marcar e repercutir na vida adulta de Bachelard. Eis que estas imagens aquáticas, desejando "re-cord-ação", inspiram a escrita de "A água e os sonhos", obra que revela a Bachelard a derrocada da luta em prol da assepsia do discurso científico. É pelo retorno à paisagem encharcada da infância, que a água faz com que Bachelard mergulhe, definitivamente, nos devaneios noturnos da matéria, devaneios cujo teor substancialista havia sido condenado pelo Bachelard-epistemólogo.

Ao contrário do elemento água, Durand, discípulo de Bachelard, acredita ser o elemento terra, a que Bachelard dedica duas obras, o de maior pregnância no psiquismo do filósofo:

Se se quiser psicanalisar com simpatia o nosso psicanalista, apercebemo-nos de que a terra desempenha um papel mais fundamental nos devaneios de um continental da planície do que a água cara aos marinheiros (...) Bachelard consagra duas obras em cinco ao elemento terrestre. Quando o químico da Champanha se aventura na montanha, é ainda a terra e a rocha que ele evoca. (DURAND, 1998, p. 11)

Quanto a nós, no trajeto de Durand (1998, p.12), para quem o valor elementar, é "intensidade e obsessão", defenderemos a obsessão de Bachelard pelo elemento ígneo. Isso não só porque ele dedica três obras a este elemento, mas, sobretudo, porque este tema é o inaugural tanto nos seus estudos de epistemologia da ciência a tese de doutoramento de Bachelard refere-se a um desdobramento do calor do fogo: "Etude sur l'évolution d'un problème de physique: la propagation thermique dans les solides" (1928)- como em suas investigações da metafísica da imaginação poética.

Em relação à metafísica bachelardiana, lembremos que a obra de transição entre a vertente diurna e a noturna da sua filosofia é

Educ. e Filos., Uberlândia, v. 20, n. 39, p. 39-70, jan./jun. 2006. 
"A psicanálise do fogog" (1938), e, até mais do que isso, que "Fragmentos de uma poética do fogo" (1962), obra inacabada, traz, em tom profético, o motivo da transcendência pelo fogo, lembrando o complexo de Empédocles: "atirar-se ao fogo não é tornar-se fogo?" (BACHELARD, 1990b, p. 113). Esta obra -a última de sua vidahesitando entre os títulos "O fogo vivido", ou, "A poética do fogo", traz, na última página escrita por Bachelard, a angústia da finitude, da vida que se esvai, sem a conclusão do projeto: "fazer um livro, isso envelhece o homem. Chega o dia em que é preciso concluir, quando é preciso acabar" (BACHELARD, 1990b, p. 18).

"É preciso concluir, é preciso acabar" -obrigatoriamente- porque o desejo é continuar para sempre; isso porque, a vida acaba, mas o projeto de uma poética do fogo, tantas vezes recomeçado, não se conclui. É o destino da fênix, que a sensibilidade ígnea de Bachelard quer lembrar pela eternidade:

Será que não conseguirei fazer um capítulo final onde contarei minhas Fênix? O título seria: 'Meus sonhos feniceanos' e como subtítulo: 'O claro-escuro da vida cinzenta'. Em lugar de estar diante de minha mesa da existência, estaria diante de minha mesa da não-existência, acariciando meu nada. (BACHELARD, 1990b, p. 18)

9 Dissemos que "A psicanálise do fogo" é a obra de transição de Bachelard, porque é nela que é máxima a tensão entre os delineamentos diurno e noturno de sua filosofia, como pode ser evidenciado pelo seu ambíguo e contraditório objetivo. De um lado, a preocupação em psicanalisar o discurso científico das imagens do fogo, rumo à purificação conceitual, onde se reconhece a face diurna da filosofia bachelardiana: "Eis nosso objetivo: curar o espírito de suas felicidades, arrancálo do narcisismo que a evidência primeira proporciona, dar-lhe outras seguranças que não a posse, outras forças de convicção que não o calor e o entusiasmo; em suma, provas que não seriam em absoluto chamas!" (Bachelard, 1999b, p. 6). De outro lado, a sedução do fogo-calor conduz a metafísica de Bachelard à entrega inevitável ao cinestésico, proclamando a vitória do materialismo noturno: "É o homem pensativo que queremos estudar aqui, o homem pensativo junto à lareira, na solidão, quando o fogo é brilhante, como uma consciência da solidão" (Bachelard, 1999b, p. 4). 
Vivendo eternamente no ardor da fênix, as imagens do fogo se eternizam nas lembranças de Bachelard, eis que, então, se torna possível a difícil consciência da "não-existência" e do "nada". É devido à obsessão por este projeto ígneo, sempre presente, mas eternamente inconcluso, que defenderemos o elemento fogo como metáfora obsedante (MAURON, 1988) da existência científica e metafísica da vida e obra de Gaston Bachelard.

\section{Referências bibliográficas}

ARAÚJO, A.F e BAPTISTA, F.P. (org.) Variações sobre o imaginário: domínios, teorizações e práticas hermenêuticas. Lisboa: Instituto Piaget, 2003.

BACHELARD, G. O novo espirito científico. [ Le nouvel esprit scientifique, tradução de Juvenal Hahne Júnior] Rio de Janeiro: Tempo Brasileiro, 1968.

.A filosofia do não: filosofia do novo espírito científico. [ $\mathrm{La}$ philosophie du non: le nouvel esprit scientifique, tradução de Joaquim José Moura Ramos] In: Os pensadores. São Paulo: Abril Cultural, 1974, p.161-245.

A chama de uma vela. [La flamme d'une chandelle, tradução de Glória de Carvalho Lins] Rio de Janeiro: Bertrand Brasil, 1989.

A terra e os devaneios do repouso: ensaio sobre as imagens da intimidade. [La terre et les reveries du repos, tradução de Paulo Neves da Silva] São Paulo: Martins Fontes, 1990a.

Fragmentos de uma poética do fogo. [Fragments d'une poétique du feu, tradução de Norma Telles] São Paulo: Brasiliense, $1990 b$.

O materialismo racional. [Le matérialisme rationnel, tradução de João da Gama] Lisboa: Edições 70, 1990c.

Educ. e Filos., Uberlândia, v. 20, n. 39, p. 39-70, jan./jun. 2006. 
. A água e os sonhos: ensaio sobre a imaginação da matéria. [L'eau et les rêves, tradução de Antonio de Pádua Danesi] São Paulo: Martins Fontes, 1998.

A formação do espírito científico: contribuição para uma psicanálise do conhecimento. [La formation de l'esprit scientifique: contribution à une psychanalyse de la connaissance, tradução de Estela dos Santos Abreu] Rio de Janeiro: Contraponto, 1999a.

A psicanálise do fogo. [La psychanalyse du feu, tradução de Paulo Neves] feu2.ed. São Paulo: Martins Fontes, 19996.

A poética do espaço. [La poétique de l'espace, tradução de Antonio de Pádua Danesi] São Paulo: Martins Fontes, 2000.

A poética do devaneio. [La poétique de la rêverie, tradução de Antonio de Pádua Danesi] São Paulo: Martins Fontes, 2001a.

A terra e os devaneios da vontade: ensaio sobre a imaginação das forças. [La terre et les rêveries de la volonté, tradução de Maria Ermantina Galvão] 2.ed. São Paulo: Martins Fontes, 2001b.

. O ar e os sonhos: ensaio sobre a imaginação do movimento. [L'air et les songes, tradução de Antonio de Pádua Danesi] 2.ed. São Paulo: Martins Fontes, 2001c.

BARBOSA, E. Gaston Bachelard: o arauto da pós-modernidade. Salvador: Universitária Americana, 1993.

Caderno CICE de ensino \& pesquisa. Centro de Estudos do Imaginário, Culturanálise de Grupos e Educação da Faculdade de Educação da Universidade de São Paulo. São Paulo: Plêiade, 2000.

CHEVALIER, J. (org.) Dicionário de símbolos. [Dictionnaire des symboles, tradução de Vera da Costa e Silva (et al.)] 15.ed. Rio de Janeiro: José Olympio, 2000. 
DURAND, G. Mito, símbolo e mitodologia. [tradução de Hélder Godinho e Vitor Jabouille] Lisboa: Editorial Presença, 1982.

A imaginação simbólica. [L'imagination symbolique, tradução de Eliane Fittipaldi Pereira] São Paulo: Cultrix/EDUSP, 1988.

As estruturas antropológicas do imaginário: introdução à arquetipologia geral. [Les structures anthropologiques de l'imaginaire, tradução de Hélder Godinho] Lisboa: Editorial Presença, 1989.

Campos do imaginário. [Champs de l'imaginaire, tradução de Maria João Batalha Reis] Lisboa: Instituto Piaget, 1998.

JUNG, C.G. Os arquétipos e o inconsciente coletivo. [Die archetypen und das kollektive, tradução de Maria Luíza Appy e Dora Mariana R. Ferreira da Silva] 2.ed. Petrópolis: Vozes, 2002.

MAURON, C. Des métaphores obsédantes au mythe personnel: introduction à la psychocritique. Paris: Libraire José Corti, 1988.

PESSANHA, J.A.M. Bachelard: as asas da imaginação. In: BACHELARD, G. O direito de sonhar. 4.ed. Rio de Janeiro: Bertrand do Brasil, 1994, p. 5-31.

ROGER, B. Descobrindo a alquimia. [A la découverte de l'alchimie, tradução de Newlton Roberval Eichemberg] São Paulo: Círculo do livro, 1991. 